\title{
Costs of occupational injuries and illnesses in Croatia
}

\author{
Marijana Bađun \\ Institute of Public Finance, Zagreb, Croatia
}

[Received in October 2016; Similarity Check in November 2016; Accepted in February 2017]

Apart from influencing the quality of life, occupational injuries and illnesses can pose a large economic burden to a society. There are many studies that estimate the costs of occupational injuries and illnesses in highly developed economies, but the evidence for other countries is scarce. This study aimed to estimate the financial costs of occupational injuries and illnesses to Croatian government and employers in 2015. Workers were excluded due to the lack of data. Costs were estimated by analysing available data sources on occupational health and safety. Financial costs were grouped in several categories: medical costs, productivity losses, disability pensions, compensation for physical impairment, administrative costs, and legal costs. Unlike in other studies, the costs of compliance with occupational safety and health regulations were also investigated. In 2015, financial costs to employers were twice higher than costs to the government (HRK $604.6 \mathrm{~m}$ vs HRK $297 \mathrm{~m}$ ). Employers additionally covered around HRK $300 \mathrm{~m}$ of compliance costs. Taking into account that financial costs of occupational injuries and illnesses are significant, even without including the costs to workers, policy makers should put additional efforts into their prevention. A prerequisite is transparency in Croatian Health Insurance Fund's expenditures, as well as more detailed data on lost days from work by industries, causes of injury etc. Organisations in charge of occupational health and safety and policy makers should observe relevant statistics in monetary terms too.

KEY WORDS: cost of illness; government; health economics; health expenditures; occupational health

The costs of occupational injuries and illnesses can be considerable. According to the International Labour Organization, these costs amount to 4 per cent of annual global gross domestic product (1). In the United States, medical and indirect (productivity) costs of occupational injuries and illnesses are at least as high as the cost of cancer (2).

Cost estimates are important to policy makers who wish to implement effective policy measures in the field of occupational health and safety. A healthy and safe working environment enhances labour productivity and encourages economic growth, competitiveness, and welfare (3). However, providing a precise estimate of the cost to all stakeholders (workers, employers, government, society) is not an easy task.

Nevertheless, there are many studies that estimate the costs of occupational injuries and illnesses in highly developed economies. These countries also boast rich databases. In developing countries, on the other hand, where the risk of disability and premature death from inadequate working conditions is a much larger problem, this is not the case. When it comes to Europe, the United Kingdom is the only country for which aggregate costs of workplace injuries and work-related ill health are available. In 2013/2014 (annual average), total costs amounted to $£ 14.3 \mathrm{~b}(0.8 \%$ of GDP), which includes both financial and human costs,

Correspondence to: Marijana Bađun, $\mathrm{PhD}$, Institute of Public Finance, Smičiklasova 21, 10000 Zagreb, Tel: +385 14886 457, Fax: +38514819365, E-mail:marijana.badjun@ijf.hr but it excludes costs of occupational cancer or other longlatency diseases (4).

According to the latest available data for all EU countries, $3.2 \mathrm{~m}$ of non-fatal accidents at work happened in the EU (Britain included) in 2014 (5). Fatal accidents at work totalled 3,739. Since the incidence of accidents depends on the size of the economy, in order to compare Croatia with the EU average it is more useful to look at the incidence of accidents at work per 100,000 persons employed. The 2014 EU average for non-fatal accidents was 1,536 per 100,000 employed, while the average for fatal accidents was 1.8 per 100,000 employed. Croatia performed better than the EU average when it comes to non-fatal accidents (870) and worse in fatal accidents (1.9).

Occupational illnesses have a much larger role in morbidity and mortality than occupational injuries, yet far less is known about the former than the latter (1). Nationally comparable data on occupational illnesses incidence or prevalence are not available. In the United Kingdom, the number of new ill health cases resulting in over seven days off work represented less than $25 \%$ of all incidence cases (injuries and illnesses combined) but accounted to nearly $65 \%$ of the total costs (4). In Croatia, around 16,000 work injuries were reported in 2015 and only 115 occupational diseases $(6,7)$.

There is only one study in which the costs of occupational injuries and illnesses were estimated for Croatia (8). In the period from 2002 to 2009, these accounted to a yearly average of $0.4 \%$ of GDP (HRK 1.1 b). Without diminishing the efforts of the authors, the study 
only looked into productivity losses (lost working hours multiplied by gross hourly wage) as direct costs and then, without any explanation, multiplied the amount by four in order to obtain total costs (direct and indirect). The authors concluded that costs in Croatia were much lower than the world average, and considered Croatian occupational health and safety policy more successful.

The aim of this study is to estimate the financial costs of occupational injuries and illnesses to Croatian government and employers in 2015. Unlike in the previously mentioned research on Croatia, which considered only productivity costs, this paper took also into account medical costs, disability pensions, compensation for physical impairment, administrative costs, and legal costs. Furthermore, contrary to international studies in this field of research, costs of compliance with occupational health and safety regulations are also investigated. Due to a lack of data, human costs are excluded from the analysis, as well as the current value of future costs (such as lost income) incurred from injuries and illnesses that occurred in the observed year. Workers bear these costs and hence they are not included in the analysis.

Without estimates for workers, it is not possible to estimate the total costs to Croatian society. However, the results of this paper still provide a relevant background for determining further research directions in the field of occupational health and safety. The main result is that in 2015 the financial costs to employers were twice higher than the costs to the government. The leading policy recommendation is that organisations in charge of occupational health and safety and policy makers should observe relevant statistics in monetary terms too.

\section{METHODS}

\section{Overview of cost estimation methods}

Reviews of various methods for estimating the costs of accidents and ill-health at work are already available and their main findings are presented here $(1,3,9)$. First of all, costs can be grouped into three categories: direct, indirect, and human costs. There is no agreement upon what each category includes. In general, direct costs refer to treatment of the injury or illness. Hence, the main component are medical costs. They are insured, usually easy to measure, and do not call for the use of special estimation methods. Sometimes companies' property damage, emergency services, and funeral costs are included as components of direct costs.

Indirect costs relate to the costs of lost opportunities for the injured or ill worker, his/her family and co-workers, the employer, and the community. They involve mainly productivity losses but also administrative costs, legal costs, and costs of household work that cannot be performed after the injury or during illness. Indirect costs are usually not insured, which makes them more difficult to measure. Human capital method is the commonly used method for estimating indirect costs, but friction cost method is also applied.

The human capital method perceives a worker's contribution to society as his contribution to the gross domestic product (GDP), which can be estimated by his wage. If productivity decreases, so does the GDP. For shortterm absences, productivity losses can be calculated by multiplying days of absence by daily wage. In case of long absences, when productivity is affected for several years, the human capital method adopts an estimate of the present value of future earnings. In case of death, future earnings are discounted from the year of death until the expected year of retirement.

While the human capital method advocates the claim that an occupational injury or illness decreases the quantity of human capital available in the economy, and thereby reduces society's capacity to produce goods, the friction cost method proponents believe that there are several mechanisms within companies and the labour market that enable a rather quick replacement of the injured or ill worker. As a result, estimates obtained by the friction cost method are much smaller than that obtained by the human capital method.

In addition to direct and indirect costs, more recent studies additionally estimated human costs, also called pain and suffering costs or quality of life costs. Noteworthy, human costs could also be considered as the most indirect costs. Human costs refer to the value of the change in the quality of life of the worker and people who surround him/ her. These costs are the most difficult to measure and easy to question, but they tend to be large. There are three methods to estimate human costs: willingness to pay, health status indices, and jury awards.

The willingness to pay method is based on estimating the amount of money that an individual or society is ready to pay or receive in exchange for a reduced risk exposure to injury, illness, or death. The quality-adjusted life year (QALY) or disability-adjusted life year (DALY) method evaluate the change in an individual's health status. The jury awards method is gaining popularity in the United States studies and it is based on the assumption that the costs of decreased quality of life can be estimated as the difference between the compensations assigned by a jury and the financial costs demanded by the victim. Researchers sometimes combine several methods in order to get the most accurate estimates.

In general, the choice of the method to be applied depends on data availability and the reason why costs are being estimated. A complete estimate of the costs of occupational injuries and illnesses is not needed in all circumstances (9). It is more useful to use a cost estimation method that will bring results reliable enough to act as a foundation for decision making. It is particularly important to avoid the issue of double-counting when aggregating 
costs to the societal level. The costs for the society are not simply the sum of the costs between various stakeholders. For example, social welfare payments (transfer costs) should be removed at the level of the society but not at the level of government. The European Agency for Safety and Health at Work (EU-OSHA) singled out the UK and Australia as good methodological examples $(3,4,10)$.

Cost estimates vary among countries depending on the number of occupational injuries and illnesses but also on the chosen methodology. As already mentioned in the Introduction, in the United Kingdom in 2013/2014 costs amounted to $0.8 \%$ of GDP, which includes both financial and non-financial human costs but not the costs of occupational cancer or other long-latency diseases (4). Financial costs contain productivity costs, health and rehabilitation costs, administrative and legal costs, and compensation. Human non-financial costs were estimated by using the willingness to pay method.

In Australia in 2012/2013 costs to employers, workers and the community were approximately $4.1 \%$ of GDP and did not include pain and suffering costs (10). However, unlike in the United Kingdom, expected future costs of incidents occurring in the reference year were included. The costs that an injury or illness imposes in future years were discounted to present values. Costs were grouped in the following categories: production disturbance costs, human capital costs (long-run costs), medical costs, administrative costs, transfer costs (deadweight losses associated with the administration of taxation and welfare payments), and other costs (for example cost of carers).

The economic burden of occupational injuries and illnesses in the United States in 2007 was $1.8 \%$ of GDP (2). Apart from medical costs, several indirect costs were included: current and future lost earnings, fringe benefits, and home production (e.g. cooking, cleaning, taking care of children, home repairs). In Singapore in 2011 costs were estimated to be $3.2 \%$ of GDP, without pain and suffering costs but including the net loss of future earnings (11). In a study on Québec in the period 2005-2007, three methods were used to come up with the estimates: willingness to pay, DALY, and human capital method (12). A study on costs of occupational injuries and illnesses in Bangkok in 2008 included medical expenses, rehabilitation costs, funeral compensation costs, and work compensation costs for lost earnings (13). These examples show that it is not wise to compare headline figures in papers without taking into consideration differences in the methodologies applied.

\section{Cost estimation method and data for Croatia}

Researchers usually count occupational injuries and illnesses and then calculate the costs (bottom-up approach). An important statistical problem concerning accidents at work is underreporting (1). Eurostat singled out Bulgaria, Latvia, Lithuania, and Romania as the most troublesome examples, but Croatia is surely not an exception. Even in the United States, probably around $40 \%$ of non-fatal injuries are not recorded (2). This problem stems from either employers' ignorance or their fear of the financial damage for the company, which is due to greater needs for investment in safety at work or potential legal costs (14). Another issue is "black economy". In developing countries, only about one in ten workers is within the reach of occupational health and safety laws (15). However, severe and fatal accidents are almost always reported, which makes the statistics more accurate.

Apart from underreporting, problems in Croatia also lie within the recorded data. Specifically, there are three sources of occupational injuries and illnesses statistics: Croatian Bureau of Statistics (CBS), Croatian Institute for Health Protection and Safety at Work (CIHPSW), and Croatian Institute of Public Health (CIPH). They all provide different numbers of occupational injuries and all use the same source: Croatian Health Insurance Fund (CHIF). Even the numbers on fatal injuries do not match; the CIPH cites as sources not only the CHIF but also the Labour Inspectorate and the Statistical Report on Death. The CIHPSW noted that the data on fatal injuries only showed the number of injuries that led to the death of the injured person up to the moment of the drawing of report on occupational injury (14). Under the Eurostat's ESAW methodology, fatal injury is an injury which leads to death within one year of the injury.

The variation in non-fatal injuries is probably due to the fact that occupational injuries can be reported up to three years from their occurrence, and there are also inaccuracies in the use of terms, for example: "a) the number of accidents at work reported in a given year (which may have occurred, e.g. two years ago); b) the number of accidents at work reported and occurred in a given year; and c) the number of accidents at work recognised by the CHIF for a given year" (14). In any case, in order to avoid such discrepancies in national statistics, a unified methodology should be used. The ESAW methodology takes into account occupational injuries reported in the observed year, but excluding injuries on the way to and from work. In sum, the CIPH data seem to be the most credible and have the longest time-span.

In this study, only the financial costs (direct and indirect) to government and employers are estimated for Croatia. Estimating the costs to workers is beyond the scope of this study due to data limitations. In addition, the standpoint of the International Labour Organization is that imputations of human costs may not be productive in achieving the goals of a cost research, i.e. providing decision makers with a basis for wise allocation of scarce resources (1). Direct costs in this analysis include medical costs, and indirect costs consist of productivity losses, disability pensions, compensation for physical impairment, administrative costs, and legal costs. In addition, unlike in previous research, the costs of complying with occupational health and safety 
regulations are also taken into account. Each of these is elaborated in the Results section.

The main data sources by components are (16 - 21): a) CHIF (medical costs, productivity losses, legal costs); b) Croatian Pension Insurance Institute - CPII (disability pensions, compensation for physical impairment, legal costs); c) CIHPSW (administrative costs); d) Institute for the Advancement of Safety at Work - IASW (administrative costs, compliance costs); e) Poslovna Hrvatska (compliance costs); f) Ministry of Finance (administrative costs).

\section{RESULTS AND DISCUSSION}

\section{Medical costs}

In Croatia, there is a compulsory contribution for occupational health protection. The contribution payer is the employer, the rate is $0.5 \%$, and the monthly calculation base is the gross salary or earnings from employment subject to personal income tax. The contribution is also payable by self-employed persons and other categories of insured persons defined in the Contributions Act. Revenues from the contribution are used by the CHIF to finance rights in cases of occupational injuries and illnesses: a right to health protection and a right to financial compensation. The latter will be explained in the following section and the right to health protection includes: a) primary, specialist, consultative and hospital health protection; b) a right to drugs, dental, orthopaedic, and other aids, all determined in the CHIF's basic and supplementary lists; c) health protection in other Member States and third countries; d) specific health protection measures, primarily preventive medical examinations of employees. CHIF covers the full costs of medical services for the entire treatment of recognised occupational injuries and illnesses.

CHIF's expenditures for health protection in cases of occupational injuries and illnesses stood at around HRK $78.6 \mathrm{~m}$ in 2015. Part of the amount was spent for the settlement of liabilities from the previous period, whereas part of the current period's liabilities remained unsettled. The expenditures decreased from 2011 to 2014 but rose again afterwards. Expenditures for health protection in cases of occupational injuries and illnesses also include outlays on specific health protection, primarily preventive medical examinations at the expense of CHIF, the cost of which is around HRK $45 \mathrm{~m}(200,000$ examinations at the price of HRK 225 per examination). It should be noted that CHIF also pays compensation of damages to persons suffering from asbestosis, although these costs are not included in the health protection expenditures (the amount paid in 2015 is HRK $20 \mathrm{~m}$ ).

Data on health protection expenditures should be taken with some reservations. According to the information provided by CHIF upon an Access to Information Request, expenses related to work injuries and occupational illnesses, which were incurred from the moment of the relevant event until the recognition of the right arising from the reported injury or illness (and this is when the expenses reach their peak), are not recorded as occupational health protection expenses but are included in the general health protection expenditures within the basic health insurance. This is also how they are presented in the annual reports of CHIF, which currently has an inadequate technical capacity to separate the occupational health protection expenses. In 2014, the average period from the receipt of a report to the recognition of the right was 37 days. Some reports of work injuries are simple and can be recognised almost immediately, by certifying the report, whereas others are more complex, e.g. when there are inconsistencies in the statements of the injured person, witnesses and the employer, as well as in the police report, or when legal proceedings or Labour Inspectorate investigation are pending, etc. Reports of occupational illnesses include special medical diagnostic and evaluation procedures, harmonisation of medical opinions concerning the diagnoses, etc. Also, according to the Compulsory Health Insurance Act, accidents at work and occupational illnesses can be reported even three years after their occurrence and all costs incurred during that period are borne by the compulsory (basic) health insurance.

\section{Productivity losses}

The right to financial compensation includes the following: a) salary compensation during the temporary inability to work (sick leave); b) reimbursement of transportation costs related to the use of health care services; c) reimbursement of funeral costs in case of an insured person's death, directly caused by a recognised accident at work or an occupational illness. The first item is here considered as the productivity loss: salary paid during absence from work. The salary compensation is calculated and paid by the employer from the first day of the inability to work, and CHIF is obliged to refund the employer within 45 days from the day of receipt of the refund request.

The salary compensation amounts to $100 \%$ of the salary compensation base and the maximum amount is not limited. Moreover, in case of an occupational injury or illness, the payment of salary compensation is not subject to the minimum service period prescribed by the Compulsory Health Insurance Act. The salary compensation provided by CHIF at a rate of $100 \%$ of the base can be continuously paid for a maximum of 18 months for the same disease diagnosis. After the expiry of that period, an insured person is entitled to a salary compensation of $50 \%$ of the last salary compensation paid, as long as there is a medical indication for such temporary inability to work. After 12 months of continuous sick leave, the selected family doctor refers the insured person to a Single Body of Expertise for the assessment of his/her ability to work.

In 2015, salary compensation for occupational injuries and illnesses paid by CHIF totalled around HRK $168.4 \mathrm{~m}$. 
The amount of salary compensation declined from 2011 to 2014 , but resumed growth in 2015 , by as little as $1.7 \%$ from 2014. It is worth noting that this expenditure item also includes health care-related travel expenses, transportation costs of deceased persons and reimbursement for drugs. However, salary compensation accounts for as much as 99 $\%$ of the said amount.

\section{Disability pensions and compensation for physical impairment}

Due to a partial or total loss of working ability, an insured person may exercise the right to disability pension. If the loss of working capacity is caused by an occupational injury or illness, the entitlement to disability pension can be acquired regardless of the length of employment. For the analysis of disability pensions by cause of disability, CPII data were obtained upon an Access to Information Request and refer to data available on 10 March 2016 (close enough to the end of 2015). Only disability pensions under general pension insurance law were considered, while special regulations were excluded. On the given date, there was a total of about 201,200 disability pensions (including those that were by law transformed into old age pensions starting from 2015, which applies only to beneficiaries older than 65 for which the cause of disability was illness).

Illness is the predominant cause of disability $(91.6 \%)$, injuries in the workplace have a share of $2.9 \%$, work injuries in traffic $0.1 \%$. Occupational illness is the cause of disability for $0.5 \%$ beneficiaries and the combination of occupational illness and injury at work is the cause of disability for $0.3 \%$ beneficiaries. The total estimated annual expenditures on disability pensions realised only under the general pension insurance law for occupational injuries amounted to HRK $167.3 \mathrm{~m}$, and for occupational illnesses HRK 26.4 m. If Croatian Homeland War Veterans are also included, extra HRK $7.8 \mathrm{~m}$ should be added to the expenditure for pensions caused by occupational injuries and illnesses.

The right to compensation for physical impairment can be obtained when physical impairment of at least $30 \%$ was created as a result of occupational injury or illness. In December 2015, there were 71,170 beneficiaries, and the amount spent by CPII was around HRK $111.5 \mathrm{~m}$. Special regulations are excluded. An insured person who has had an accident at work or suffers from an occupational illness is also entitled to professional rehabilitation, but in 2015, there was only one new beneficiary of this right.

\section{Administrative costs}

Numerous institutions act in the area of health and safety at work in Croatia: Department of Health Protection at Work, which is an organisational unit of CHIF, Department of Occupational Safety in the Ministry of Labour and Pension System, CPII, CIPH, the Ministry of Health, Labour Inspectorate (administrative unit within the Ministry of
Labour and Pension System), Croatian Association of Occupational Medicine, Department of Environmental and Occupational Medicine (School of Medicine, University of Zagreb), Institute for Medical Research and Occupational Health. There is also a National Council for Occupational Safety and Health, which was established to advise the Government.

Since the expenditures of various organisational units are integrated in the total expenditures, only the expenses of CIHPSW and IASW, the main organisations in this field, can be clearly identified. CIHPSW, established in 1996, deals with various aspects of improving the health and safety of workers and has 49 employees. In 2015, the Institute achieved around HRK $7.5 \mathrm{~m}$ revenue, of which about HRK $7.3 \mathrm{~m}$ were received from the state budget. In 2015, employees accounted for the bulk of the expenditures (HRK $5.6 \mathrm{~m}$ out of HRK $7.4 \mathrm{~m}$ ) It is interesting that during 2015, the Institute had HRK $9.5 \mathrm{~m}$ financial assets, of which HRK $8.8 \mathrm{~m}$ in cash. IASW, established in 2014, is the central public organisation responsible for monitoring and improving occupational safety. It has 16 employees and an administrative council of five members. Expenditures in 2015 , financed from the state budget, amounted to HRK $1.6 \mathrm{~m}$.

\section{Legal costs}

CHIF is required to claim damages caused by the person who induced the illness, injury, or death of the insured person. Damage claim is addressed to the employer (or the employer's insurance company), unless it was caused intentionally or by gross negligence by the worker. Furthermore, CHIF is required to claim damages caused by natural or legal persons if the illness, injury, or death of the insured person came about due to the fact that safety measures have not been implemented, including the obligatory preliminary medical examination of workers. In all these cases, compensation includes expenses for health care and other services and the amount of fees and other charges paid by CIHI. According to the data for 2015, revenues from occupational injuries incurred abroad amounted to HRK 344,000 (only one case won in court, which was initiated in 2002). Income from injuries that occurred in Croatia amounted to HRK 245,155. Court proceedings usually last for several years.

CPII has the right to demand compensation for monetary benefits paid at the expense of pension insurance throughout the period of the payment of benefits in full and although these benefits are insured. This refers to (a) cash benefits paid on the basis of the recognised right to a pension in full amount, (b) cash benefits based on recognised rights to compensation for physical impairment, and 3) the costs of professional rehabilitation. If the damage was caused by the worker, the employer and the worker pay together. If the damage was caused because safety measures have not 
been implemented, the employer is charged. In 2015, CPII collected on the basis of damages around HRK $24.8 \mathrm{~m}$.

\section{Compliance costs}

IASW issues authorisations to companies dealing with occupational safety. In August 2016, 136 natural and legal persons were authorised to perform safety at work measures. Authorisations are given for providing trainings for safe work, making risk assessments, testing work equipment, and testing the effects of physical factors and chemical effects. Revenues of the companies authorised to perform occupational safety activities in 2015 were around HRK $300 \mathrm{~m}$. This number applies to the entities providing occupational health services to third subjects, while the value of services provided within companies by occupational safety experts is not included. Almost $40 \%$ of the total market value of the services provided in the area of occupational safety and health concerns 9 largest companies. The authorised companies employed around 1,100 workers in 2015 .

\section{Costs by bearers}

Workers bear all human costs, which are not included in this study. In addition, workers experience future income losses, which is also not taken into account. However, employers bear the largest (current) financial burden of occupational injuries and illnesses, both when it comes to prevention and treatment. In 2015, employers paid HRK $579.6 \mathrm{~m}$ on behalf of contributions for occupational health protection. The expenditures on salary compensation and health protection in cases of occupational injuries and illnesses were HRK 247 m. Hence, the gap between CHIF's revenues and expenditures for occupational health protection in 2015 amounted to HRK $332.6 \mathrm{~m}$. In other words, it seems that $57 \%$ of the collected revenues were spent inappropriately. However, these data should be taken with some reservations.

As already mentioned, CHIF depends on some external factors when processing the reports of occupational injuries and illnesses. Furthermore, the amount of administrative expenditures for occupational health protection is unknown because these costs are included in CHIF's total administrative expenditures. Nevertheless, it is still unclear why it does not have a separate business fund for compulsory health insurance in the cases of work-related accidents and diseases, as provided by the Compulsory Health Insurance Act and CHIF's Statute. It is of utmost importance to set up a separate business fund and then review the rate of contribution.

Apart from contributions for occupational health protection, employers also paid around HRK $25 \mathrm{~m}$ of legal costs to CPII and CHIF. In addition, employers furthermore bear the burden of legal compensations for immaterial damage suffered by workers (physical pain, different forms of emotional distress, fear, deterioration of physical appearance). Unfortunately, the Ministry of Justice does not have data on labour disputes stemming from immaterial damage lawsuits, but such costs can be high and detrimental for a company's survival. Availability of these data would make it possible to partly estimate human costs by using the jury award method. In addition, occupational injuries affect employers' insurance premiums. Finally, employers must bear most of the burden of ensuring a healthy and safe workplace. In sum, employers paid around HRK 300 m for prevention and HRK $604.6 \mathrm{~m}$ for medical expenses, sick leave and legal costs to CPII and CHIF. Altogether, HRK $904.6 \mathrm{~m}$, which approximately equals to $15 \%$ of government's revenues from corporate income tax (profit tax).

The government (i.e. CPII) spent HRK $201.5 \mathrm{~m}$ on disability pensions caused by occupational injuries and illnesses (including Croatian Homeland War Veterans but not other special categories). In addition, expenditures on compensation for physical impairment were HRK $111.5 \mathrm{~m}$. Altogether, HRK 313 m. Occupational injuries and illnesses can also affect an individual's decision to enter early retirement, which is not taken into account in this study. CHIF also paid HRK $20 \mathrm{~m}$ as an indemnity to persons suffering from asbestosis, but it is not clear if this amount is covered by employers' contributions for occupational health protection. It is worthwhile to note that approximately $45 \%$ of CPII's expenditures are covered from the state budget and not workers' pension contributions.

In Croatia, OSH seems to be a relatively high priority, since there are many institutions dealing with this matter. The functioning of two main institutions in charge of occupational safety and health cost government HRK $8.9 \mathrm{~m}$. However, their work is not coordinated.

To conclude, the financial costs of occupational injuries and illness to employers in Croatia in 2015 were around HRK $604.6 \mathrm{~m}$. Government expenditures on occupational injuries and illnesses amounted to around HRK $322 \mathrm{~m}$, but the government also collected HRK $25 \mathrm{~m}$ in legal fines from employers. Hence, costs to government were HRK 297 m. Costs to employers were twice as high as the costs to government.

\section{CONCLUSION}

It does not seem productive to compare the costs of occupational injuries and illnesses in Croatia to the costs obtained in other countries due to the inclusion of different cost components and various methods applied. When comparing the results of this study with previous research on Croatia, it seems that Croatian occupational health and safety policy is not that successful as earlier perceived. To be precise, in this paper, only the government's and employers' financial costs in 2015 were around HRK $900 \mathrm{~m}$ ( $0.3 \%$ of GDP), while an earlier estimate of total costs (2002-2009 yearly average) was HRK 1.1 b (0.4\% of GDP). 
In all studies, human costs are the largest part of costs, which means that total costs to Croatia greatly exceed HRK $900 \mathrm{~m}$. In the United Kingdom, workers bear $57 \%$ of costs, government $24 \%$, and employers $19 \%$.

The research in this paper might seem rudimentary compared to the research on the United States, Australia, the United Kingdom or Canada, but this impression is unfortunately largely driven by data availability. The most important policy issues in the field of occupational health in Croatia relate to transparency and data availability. A wide range of public health policies can also be made more effective - better targeted, prioritised and integrated - with appropriate data. Firstly, CHIF's expenditures should be trackable by industries and causes of injury and the exact amount of medical costs have to be known. In addition, occupational injuries should be separated from occupational illnesses. Furthermore, the number of accidents at work must be the same in all official sources. Rich databases would be the strongest impulse for additional research in this field. Unfortunately, health economics is largely neglected in Croatia. With scarce government resources, it is especially important that policy changes in the field of health are thoroughly analysed in economic terms.

One of the shortcomings of this paper is that it takes into account only recorded accidents at work and occupational illnesses. To deal with unrecorded data, Labour Force Survey should include questions on occupational injuries and diseases. Currently, survey respondents are only required to state the reason why they were not working and one of the options is "disease and injury", but this is too general.

Since employers pay a large sum of money for prevention of occupational injuries and illnesses and the financial costs are still high, the government needs to examine the efficiency of current legal framework on occupational safety and health. Furthermore, activities of occupational medicine specialists should also be looked into since the option to educate workers is largely neglected (focus is on preventive medical examinations).

\section{Acknowledgements}

The author would like to thank Stipan Barać (Croatian Health Insurance Fund) and Gordana Živec Šašić (Croatian Pension Insurance Institute) for data provision and helpful comments during this research. In addition, the author is grateful to the participants of regional workshops held within the project "Parity Fund to Strengthen Social Dialogue in the Construction Sector".

\section{Competing interests}

This article follows the research project "Parity Fund to Strengthen Social Dialogue in the Construction Sector" managed by the Croatian Employers' Association (CEA) and co-financed by the European Social Fund. The views expressed in this article are those of the author and do not in any way represent the position or official views of the CEA. There is no conflict of interest.

\section{REFERENCES}

1. International Labour Office. Estimating the economic costs of occupational injuries and illnesses in developing countries: Essential information for decision-makers. Geneva: ILO; 2012 [displayed 26 Jul 2016]. Available at http://www.ilo. org/safework/info/publications/WCMS_207690/lang--en/ index.htm

2. Leigh JP. Economic burden of occupational injury and illness in the United States. Milbank Q 2011;89:728-72. doi: 10.1111/j.1468-0009.2011.00648.x

3. European Agency for Safety and Health at Work. Estimating the cost of accidents and ill-health at work: A review of methodologies. Bilbao: EU-OSHA; 2014 [displayed 26 Jul 2016]. Available at https:/osha.europa.eu/en/publications/ reports/estimating-the-costs-of-accidents-and-ill-health-atwork/view

4. Health and Safety Executive. Costs to Britain of workplace fatalities and self-reported injuries and ill health, 2013/14. London: HSE; 2015 [displayed 6 Jul 2016]. Available at http://www.hse.gov.uk/statistics/pdf/cost-to-britain.pdf

5. Eurostat. European Commission: Health and safety at work [dataset] [displayed 20 Dec 2016]. Available at http://ec. europa.eu/eurostat/web/health/health-safety-work/data/ database

6. Croatian Institute for Health Protection and Safety at Work. Analiza ozljeda na radu 2015 [Analysis of work injuries in 2015, in Croatian]. Zagreb: CIHPSW; 2016 [displayed 27 Jul 2016]. Available from: http://www.hzzzsr.hr/images/ documents/ozljede $\% 20 \mathrm{na} \% 20 \mathrm{radu} /$ Analiza $\% 20$ ozljeda $\% 20$ na\%20radu/Analiza_ONR_2014/ANALIZA_ONR_2015. pdf

7. Croatian Institute for Health Protection and Safety at Work. Registar profesionalnih bolesti za 2015 [Occupational Illnesses Registry in 2015, in Croatian]. Zagreb: CIHPSW; 2016 [displayed 27 Jul 2016]. Available from: http://www. hzzzsr.hr/images/documents/Godi\%C $\%$ A 1 nje $\% 20$ izvje $\%$ C $5 \%$ A $1 \%$ C4\%87e/1Registar_profesionalnih_ bolesti 2015.godinu.pdf

8. Vojak N, Plazonić H, Taradi J. Troškovi zbog ozljeda na radu i profesionalnih bolesti u Hrvatskoj u odnosu na bruto domaći proizvod kao ekonomski pokazatelj uspješnosti organizacije sustava sigurnosti na radu [The costs of workplace injuries and occupational diseases in relation to gross domestic product as an economic indicator of effectiveness in organizing the occupational safety systems in Croatia, in Croatian]. In: Taradi J, Filipović AM, editors. Organiziranje i sigurnost: zbornik radova VI. znanstveno-stručne konferencije s međunarodnim sudjelovanjem "Menadžment i sigurnost". Čakovec: Hrvatsko društvo inženjera sigurnosti; 2011. p. 157-69.

9. Lebeau M, Duguay P. The Costs of Occupational Injuries: A Review of the Literature. Studies and Research Projects, Report No. R-787. Montréal: IRSST; 2013.

10. Safe Work Australia. The Cost of Work-related Injury and Illness for Australian Employers, Workers and the Community: 2012-13. Canberra: Safe Work Australia; 2015 
[displayed $25 \mathrm{Jul}$ 2016]. Available at http://www. safeworkaustralia.gov.au/sites/SWA/about/Publications/ Documents $/ 940 /$ cost-of-work-related-injury-anddisease-2012-13.docx.pdf

11. Loke YY, Tan WJ, Manickam K, Heng P, Tjong C, Lim GK, Lim S, Gan SL, Takkala J. Economic Cost of Work-related Injuries and Ill-health in Singapore. Singapore: Workplace Safety and Health Institute; 2013 [displayed 14 Dec 2016]. Available at https://www.wsh-institute.sg/files/wshi/upload/ $\mathrm{cms} /$ file/Economic $\% 20$ Cost $\% 20$ of $\% 20$ Work-related $\% 20$ Injuries $\% 20$ and $\% 20$ Ill-health $\% 20$ in $\% 20$ Singapore.pdf

12. Lebeau M, Duguay P, Boucher A. Costs of occupational injuries and diseases in Québec. J Safety Res. 2014;50:89-98. doi: 10.1016/j.jsr.2014.04.002

13. Thepaksorn P, Pongpanich S. Occupational injuries and illnesses and associated costs in Thailand. Saf Health Work 2014;5:66-72. doi: 10.1016/j.shaw.2014.04.001

14. Bađun M. The contribution for occupational health protection. Zagreb: Institute of Public Finance; 2016. Newsletter No. 106. doi: 10.3326/nle.2016.106

15. LaDou J. International occupational health. Int J Hyg Environ Health 2003;206:303-13. doi: 10.1078/1438-4639-00226

16. Croatian Health Insurance Fund. Izvješće o poslovanju Hrvatskog zavoda za zdravstveno osiguranje za 2015. godinu [Report on Croatian Health Insurance Fund performance in 2015, in Croatian]. Zagreb: CHIF; 2016 [displayed 4 Aug 2016]. Available at http://www.hzzo.hr/wp-content/
uploads/2016/04/Izvjesce_o_poslovanju_hzzo_za_2015 godinu.pdf?6d8ad4

17. Croatian Pension Insurance Institute [dataset]. Zagreb: CPII. 2016 [displayed 4 Aug 2016]. Available upon an Access to Information Request at http://www.mirovinsko.hr/default. aspx?id=166

18. Croatian Institute for Health Protection and Safety at Work. Godišnje izvješće za 2015. godinu [Annual report for 2015, in Croatian]. Zagreb: CIHPSW; 2016 [displayed 4 Aug 2016]. Available at http://hzzzsr.hr/images/documents/ Godi\%C5\%A 1 nje \%20izvje\%C5\%A1\%C4\%87e/ Izvje $\% \mathrm{C} 5 \% \mathrm{~A} 1 \% \mathrm{C} 4 \% 87 \mathrm{e}-\mathrm{HZZZSR}-2015 . \mathrm{pdf}$

19. Institute for the Advancement of Safety at Work. Evidencije ovlaštenja [Authorization records, in Croatian]. Zagreb: IASW; 2016 [displayed 4 Aug 2016]. Available at http:// zuznr.hr/znr/ovlastenja/

20. Poslovna Hrvatska [dataset]. Zagreb: P.H; 2016 [displayed 4 Aug 2016]. Available at http://nova.poslovna.hr/lite/info/ tour.aspx

21. Ministry of Finance. Prijedlog godišnjeg izvještaja o izvršenju Državnog proračuna Republike Hrvatske za 2015. godinu [The proposal of the annual report on the execution of the State Budget of the Republic of Croatia for 2015, in Croatian]. Zagreb: MF; 2016 [displayed 4 Aug 2016]. Available at http://www.mfin.hr/hr/drzavni-proracun-2015godina

\section{Troškovi ozljeda na radu i profesionalnih bolesti u Hrvatskoj}

Osim što utječu na kvalitetu života, ozljede na radu i profesionalne bolesti mogu biti velik ekonomski teret za društvo. Provedena su brojna istraživanja u kojima su se procjenjivali troškovi ozljeda na radu i profesionalnih bolesti u visoko razvijenim gospodarstvima, no vrlo je malo takvih istraživanja za ostale zemlje. Cilj ovoga istraživanja bio je procijeniti koliki su u 2015. bili financijski troškovi hrvatske države i poslodavaca u pogledu profesionalnih bolesti i ozljeda na radu. Radnici su bili isključeni iz analize zbog nedovoljno podataka. Troškovi su procijenjeni analizom raspoloživih izvora podataka o zaštiti zdravlja na radu. Financijski su troškovi raspoređeni u nekoliko kategorija: medicinski troškovi, gubici u produktivnosti, invalidske mirovine, naknada za tjelesno oštećenje, administrativni troškovi i pravni troškovi. Za razliku od drugih istraživanja, u ovom su uzeti u obzir i troškovi provedbe mjera zaštite na radu. U 2015. financijski troškovi poslodavaca bili su dvaput veći od državnih (604,6 mil. nasuprot 297 mil. HRK). Poslodavci su dodatno platili oko 300 mil. HRK za provedbu mjera zaštite na radu. Uzimajući u obzir da su financijski troškovi povezani s profesionalnim bolestima i ozljedama na radu značajni, čak i bez troškova za radnike, nositelji politike trebali bi dodatno poraditi na prevenciji. Prethodno je potrebno povećati transparentnost izdataka Hrvatskoga zavoda za zdravstveno osiguranje i učiniti raspoloživim podatke o izgubljenim radnim danima po industrijama, uzrocima ozljede itd. Organizacije zadužene za zaštitu zdravlja i sigurnost na radu i nositelji politike trebali bi razmatrati i ekonomske aspekte statističkih podataka.

KLJUČNE RIJEČI: država; ekonomika zdravstva; Hrvatska; izdaci za zdravstvo; ozljede na radu; profesionalne bolesti; trošak bolesti; zaštita zdravlja na radu 